\title{
WHY HOUSEHOLDS IN THE UNITED STATES DO NOT MAINTAIN THEIR SEPTIC SYSTEMS AND WHY STATE-LED REGULATIONS ARE NECESSARY: EXPLANATIONS FROM PUBLIC GOODS THEORY
}

\author{
R. MOHAMED \\ Wayne State University, USA.
}

\section{ABSTRACT}

Septic systems are found on many residential lots. Unfortunately, the lack of maintenance by households results in the failure of these systems. In turn, this has considerable negative environmental, public health, and fiscal consequences. Governments have responded with a plethora of education programs aimed at making households aware of their systems and of the need to maintain them. Nonetheless, failure rates remain high. This article uses public goods theory to show that households do not maintain their septic systems because it is not in their rational self-interest to do so. Educating households is an insufficient response. Similarly, it is not in the rational self-interest of local governments to establish effective regulations. State-established regulations, combined with incentives and sanctions to ensure implementation by local governments, appear to offer more environmentally and fiscally sustainable solutions to the problem.

Keywords: common pool resources, lakes, land use, open access resources, pollution, prisoner's dilemma, public goods theory, rivers, septic systems, sprawl.

\section{INTRODUCTION}

Septic systems can be found on a large percentage of residential lots in the United States. According to one estimate, about $21 \%$ of all U.S. homes utilize septic systems ([1], p. 5). Another estimate puts the figure as high as $25 \%$ [2]. Evidence indicates that this number is likely to increase [3] as one-third of all new homes built contain some form of decentralized systems [4]. Some members of the leading interest group who promote the utilization of septic systems, the National Onsite Wastewater Recycling Association, advocate that $50 \%$ of all new homes should have some form of onsite disposal [5].

Unfortunately, many septic systems fail [6]. The consequences of failure include the contamination of public waters [7] and its consequent health effects [8]. Consequences can also be counted in fiscal terms, where pollution is monetized as financial damages to the environment in addition to the public costs of taking corrective measures [9]. Other scholars have also expressed concern about the land use, environmental, and fiscal sustainability of the widespread use of septic systems [9-11].

The primary response of governments to the problem of failing septic systems has been to employ a variety of education programs aimed at making households aware of their systems and of the need to maintain them, sometimes by appealing to households' sense of communal responsibility to protect the environment. A Google Internet search illustrates the role of education: Repeated searches in November 2007 using the terms "education" "septic system OR tank" produced over 1.1 million hits. This education-led response rests on a belief that households do not maintain their systems because they are "out of sight" and therefore "out of mind" [12-14].

As the primary policy response, education has had limited impact. Septic systems continue to fail at alarming rates [8, 15] and in some states this rate exceeds 50\% [16]. Given the vast exurban expansion in the United States in recent decades that utilized septic systems $[9,10,17,18]$ and the increasing percentage of new homes with them [3, 4, 19], the scale of the problem is likely to get worse. Moreover, there are no indications that planners and policy makers intend to replace education 
as the primary response to the problem; in a recent survey, officials from 24 out of 25 participating states ranked education as the first policy choice for promoting maintenance [19].

In light of the limited impact of education, it is perhaps time to step back and ask whether "out of sight, out of mind" is the only reason why households in the United States do not maintain their septic systems and, in turn, whether education should be the primary policy response. I am interested in this question not only because it is important to understand the proximate reasons why households do not maintain their systems but also because such an understanding could lead to appropriate policies to address the problem.

I address the question by drawing on public goods theory. From this perspective, I find that the salient reason why households do not maintain their septic systems is that it is not in their rational self-interest to do so. I utilize the same framework to show that the local government level is not the appropriate one at which to establish regulations, thus necessitating state-led policies.

Before proceeding, five preliminary caveats are in order. First, although this article focuses on the United States, the findings are applicable elsewhere, including rapidly urbanizing developing countries where septic systems play a large role [20]. Second, this article does not take a position in the contentious debate among academicians in the United States about the advantages or disadvantages of septic systems versus public sewers. However, the findings can inform that debate. Third, my arguments are pertinent to suburban and exurban areas - the latter on the sprawling metropolitan fringe [21] - and may be less pertinent to isolated rural areas, as I will elaborate on in Section 6. Fourth, the role of septic systems as a facilitator of land use sprawl has been discussed in older and contemporary research $[9-11,17,18,22]$, and it is not the intention of this article to add to that discussion. Finally, this article does not address why planners and policy makers chose education as the primary response. This response is related to issues of problem identification, where planners and policy makers address the "wrong problem" [23]. Discussions of why officials chose an inappropriate policy are outside the scope of this article. This article addresses only why households do not maintain their septic systems despite the widespread education efforts intended to get them to do so and extends the arguments to a consideration of the role of local governments.

The article proceeds as follows: Section 2 provides additional background on septic systems, the consequences of failure, and governments' responses. Section 3 introduces pertinent public goods theory. Section 4 utilizes the public goods framework to highlight the underlying reasons why households do not maintain their septic systems. Section 5 briefly replicates the arguments about household behavior to understand why the local government level might not be the appropriate one at which to establish regulations. Section 6 discusses additional caveats. Section 7 concludes with a discussion about ways to address the problem.

\section{THE USE OF SEPTIC SYSTEMS IN THE UNITED STATES, THE CONSEQUENCES OF FAILURE, AND THE EDUCATION RESPONSE OF GOVERNMENTS}

The conventional septic system comprises a tank and an absorption field (known as a drainfield) that is made up of soils and a pipe network (Fig. 1). The tank separates the solids from the liquid and performs partial treatment through anaerobic processes [8]. The liquid, which contains large quantities of pollutants, is further treated after it leaves the tank as it percolates through the drainfield [8].

Septic systems in the United States have been around for a long time and their usage is steadily increasing. In 1960, they were found on 14 million home sites. By 1970, that number had risen to 17 million [22] and by 2005 they could be found at about 26 million homes [1], producing about 4 billion gallons of effluent per day [8].

Growth in the use of septic systems is not the result of isolated rural development. Rather it is related to a "suburbanization of the suburbs" ([21], p. 705) that is facilitated by septic systems and 


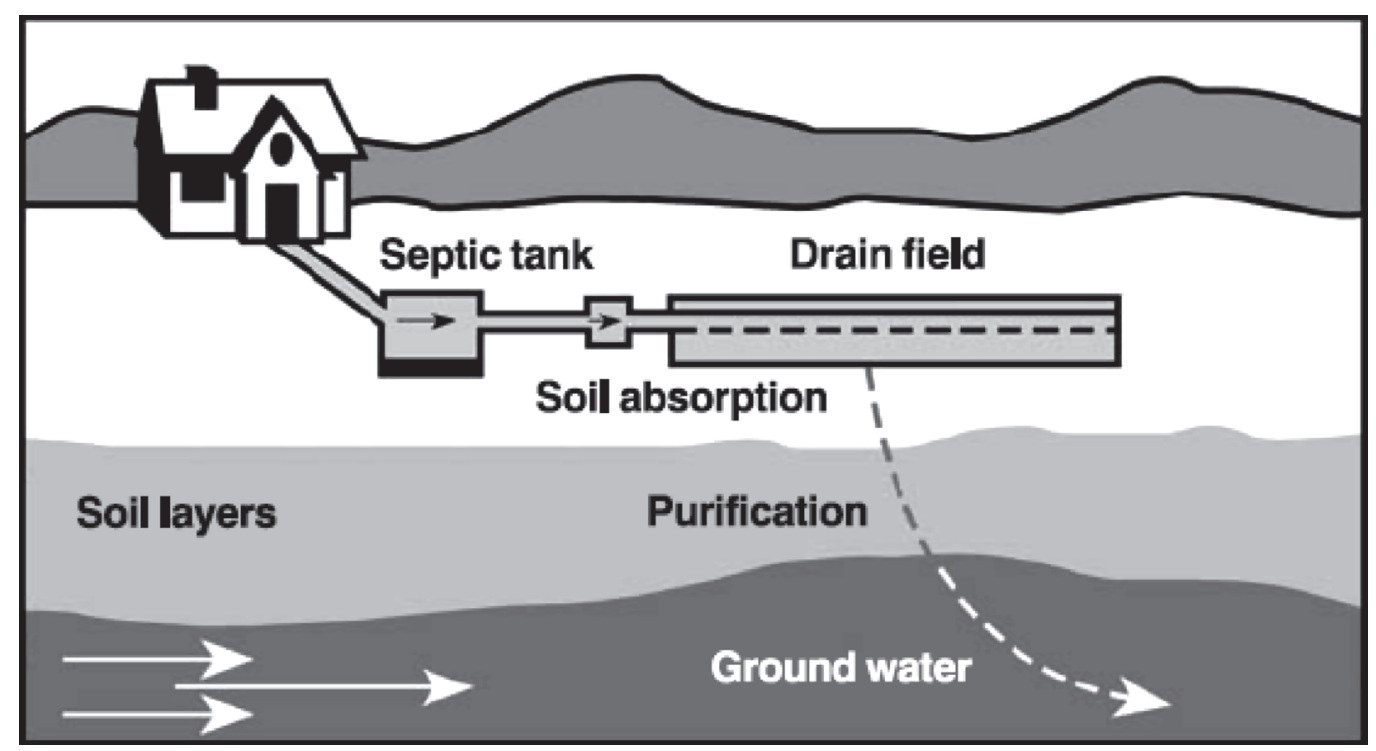

Figure 1: The conventional septic system. Source: NESC [24]. Reproduced with permission.

other technological advances [9, 10, 18, 22]. While septic systems in the United States are concentrated in the Northeast and parts of the South, many households in the Midwest, Upper Plains States, Intermountain West, and Pacific Northwest utilize them (Fig. 2). In 35 states, more than a quarter of households utilize septic systems and in nine of these states more than $40 \%$ of households utilize them. In the remaining 15 states, more than $10 \%$ of households utilize septic systems. Of the 25 states that took part in Lazarean's [19] survey, 14 reported that the share of new homes with septic systems was increasing, five said that it was holding constant, and only three reported that it was decreasing. (Two states indicated that they did not know and one state provided no answer.)

To be sure, from the perspective of individual parties, there are good fiscal reasons for choosing septic systems over public sewers when homes are built: (1) they allow developers - who, since the 1980s, have been mostly responsible for installing sewer lines - to avoid upfront expenditures [25]; (2) in turn, households find it less expensive, all else equal, to buy housing in areas without sewer lines [26]; and (3) many local governments find them attractive because they facilitate "fiscal" zoning [21].

Evidence shows that many septic systems in the United States fail [6, 27, 28]. While there is no standard definition of failure, systems are considered to have failed when soils that are supposed to filter the effluent become clogged with solids and organic matter and can no longer perform their intended function [16]. If and when this occurs depends mainly on the degree of maintenance provided by each household [2]. The primary maintenance activity is regular pumping of the tank, usually every 3-5 years [2], which reduces the chances that excess solids and organic matter will leave the system and clog surrounding soils.

The failure of septic systems is associated with the impairment of groundwater, lakes, and coastal areas [7], receiving sinks that are public environmental goods. Indeed, for some time now contamination of groundwater from septic systems has been second only to contamination from industrial uses [29]. Groundwater contamination from septic systems has been observed from New Mexico 


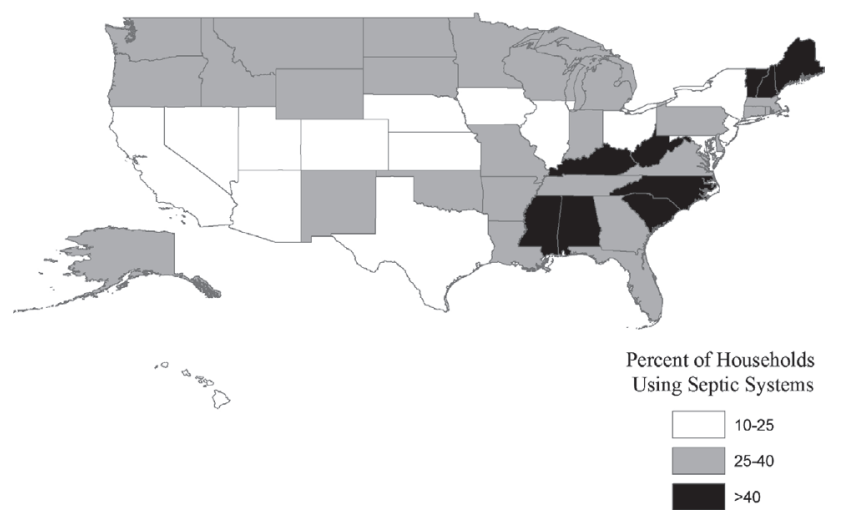

Figure 2: Septic system use across the United States. Source: USEPA [8].

[30] to Maine [31]; lake contamination from Georgia [32] to Wisconsin [33]; and, shoreline contamination from Washington [34] to North Carolina [35]. This is a representative list only. An Internet search for "septic system OR tank" pollution in November 2007 produced over 1 million hits, revealing the extent to which septic systems are associated with pollution.

Other important water bodies across the United States are also subject to severe pollution from septic systems. Severe pollution has been reported in Chesapeake Bay, the Indian River Lagoon in Florida, Buttermilk Bay in Massachusetts, and Puget Sound in Washington. A study of Chesapeake Bay found that the estimated 2 million neighboring septic systems contribute about 9 million pounds of nitrogen per year to the Bay, about $12 \%$ of the nitrogen that officials seek to remove each year through a variety of costly measures [36]. The Indian River Lagoon in Florida receives about 1.5 million pounds of nitrogen per year from 45,000 surrounding systems [15]. Similarly, about $75 \%$ of the nitrogen entering Buttermilk Bay in Massachusetts comes from septic systems [37]. In Puget Sound, Washington, shellfish beds have been routinely closed because of septic system pollution [38].

A study by Nelson et al. [16] found that systems were failing at a rate of 50-70\% in Minnesota, 60\% in West Virginia, 50\% in Louisiana, 40\% in Nebraska, 30-50\% in Missouri, 25-30\% in Ohio, and 25\% in Massachusetts. In Indiana, one study reported that as many as 70\% of the 800,000 systems in that state were failing in 1997 [39]. Burgan and Sievers [40] report the same percentage of failing systems in Missouri. These failure rates are directly related to the lack of maintenance [8]. Further, the United States Environmental Protection Agency (USEPA; [8], pp. 1-5) notes that "total failure rates and onsite system impacts over time are likely to be significantly higher than historical statistics indicate."

Meanwhile, according to the EPA, 168,000 viral and 34,000 bacterial illnesses each year can be traced to badly maintained septic systems [8]. In addition, the monetized value of environmental and public health damages could be large [41, 42].

In response to the environmental, public health, and fiscal consequences, state and local governments and quasi-governmental agencies, such as university research institutes, university extension arms, and watershed districts, have responded with a plethora of materials intended to educate households about their systems and of the need to maintain them. The list of resources is long, and the Internet searches referred to earlier reveal the extent to which education is viewed as the primary response. Representative publications include: So ... Now You Own a Septic System [43]; Everything 
You Always Wanted To Know About Septic Systems ... But Didn't Know Who To Ask! [44]; and, What Do You Mean My House Has A Septic Tank? [45]. Many of these publications appeal to households' sense of communal responsibility for the environment, for example, Inspecting Your Household Septic System [46].

However, there is little evidence that education is effective. In an insightful study in Ohio, the location of an education program using the "best available educational techniques" ([47], p. 20), the author compared the behavior of households before and after the program. He found that "At best, only a handful of residents ... responded to the educational program" ([47], p. 19). For example, the program did not lead households to use a "diverter" that would direct effluent to a portion of the drainfield while the remainder regenerated for future use. Importantly, participants reported an "increased understanding of the need to maintain their systems" but this did not lead to changes in behavior ([47], p. 20).

Similarly, studies in areas with long-standing education programs, Washington State [48] and Chesapeake Bay [49], found that less than half of households even attempt any maintenance of their septic systems.

Notwithstanding the limited success of education in reducing failure rates, there are no indications that planners and policy makers intend to replace it as the primary policy response to the problem; in Lazarean's survey, 24 of 25 participating states ranked education as the first policy choice for promoting maintenance [19]. The lack of households' response to education, however, casts doubt on whether it should be the primary policy response. Next, I review public goods theory, which will be utilized to provide an alternative perspective.

\section{A BRIEF REVIEW OF PUBLIC GOODS THEORY}

The literature on public goods is extensive. Here, I provide only a brief overview of pertinent points. For detailed discussions, see, for example, Laffont [50] and Cornes and Sandler [51].

Planners and policy makers have long been engaged in the management of impure public goods, for example, roads and open space ([52], pp. 103-107). When there are many users of these goods, one person's private use produces externalities that impose public costs ([52], pp. 37-40; [53], pp. 128-132). This is commonly referred to as a divergence between private and public costs [54], where the public subsidizes the private actions.

Public goods sometimes fall at two ends of a spectrum of ownership: common property resources (CPRs) where ownership is communal and open access resources (OARs) where ownership is not defined. CPRs are the result of certain conditions in which communal management is the classic solution to avoiding degradation of the good. Some of these conditions are (see [55] for a list, [56] for a revised list) as follows: (1) those affected by degradation of the good (when it is a sink for receiving pollution) are the only ones who use the good and (2) users of the good should be able to cooperate and trust each other. In the case of OARs, privatization is the classic solution to avoiding degradation of the good [57]. This assumes that the good can be divided and ownership transferred to private parties.

However, many goods, such as roads, fall between these two extremes. In the case of roads, it is technologically and practically possible to exclude some road users through incentives and sanctions. The toll road, with which planners and policy makers are familiar, is one such example.

Not all goods are as easy to regulate, in relative terms, as roads. Clean air is one such example. This results in the classic free rider problem where anyone can use clean air that is provided by someone else. Fortunately, it is sometimes possible to regulate air pollution because it is often emitted from a point source, making it easier to identify polluters. However, regulatory mechanisms are difficult to enforce when non-unique pollution comes from non-point sources, for example, agricultural runoff.

When enforceable regulations, either through incentives or sanctions, are not in place, the free rider problem could lead to the good being consumed or degraded to the point of destruction [57]. 
This "tragedy of the commons" [57] is an instance of the prisoner's dilemma game (for a review, see Appendix A) where a rational self-interested individual maximizes his or her payoff by defecting from attempts to manage the resource or sink through free riding on the efforts of others. Because all individuals find it in their self-interest to defect, cooperation to manage the good breaks down. Repeated games, in which participants can signal good intentions to each other, may result in trust and, hence, cooperation to preserve the good. But this is only possible when extant conditions are similar to those of CPRs.

Managing public goods is also more difficult when the initial consequences of pollution are minor and dispersed [58]. Under these circumstances, polluters' actions may go unobserved for a long time. Measures to address the problem are only taken when the consequences of the pollution become visible and the costs (defined as environmental, public health, and fiscal) begin to impinge on the polluter or wider society [59].

\section{WHY HOUSEHOLDS DO NOT MAINTAIN THEIR SEPTIC SYSTEMS}

In this section, I discuss how the characteristics of septic systems and the sinks that receive their pollution result in households finding it in their rational self-interest to defect from maintaining their systems. I construct the argument by: (1) highlighting why classical solutions - solutions to CPRs and OARs - will not work and (2) highlighting features of the situation that, in the absence of classical scenarios, lead households to defect from maintenance.

\subsection{Why classical solutions will not work}

Conditions do not exist that can result in CPRs, where communal management is possible. In most instances, the receiving sinks are relatively large water bodies that extend beyond the areas where pollution occurs, meaning that more people are affected by pollution of the sinks than the households that pollute them. Thus, one critical condition outlined by Ostrom $[55,56]$ for the existence of CPRs - that the polluters and those affected by the pollution should be the same - is absent.

In addition, in typical subdivisions it is difficult to envision circumstances under which the required trust to manage CPRs could be established, for example, among neighbors who may not know each other. It is also difficult to envisage circumstances where time (or, in the language of the prisoner's dilemma game, "repeated plays") will lead to trust. Septic system maintenance is recommended only once every 3-5 years, and much can happen during this period. A household that signaled good intentions at one point may find that 3 years later they cannot afford another round of maintenance. Or the neighbors to whom cooperation was signaled may have left the subdivision, requiring the first neighbor to recommence the process of building trust. Collectively, conditions do not exist such that the goods being polluted are CPRs and appeals to households' sense of communal responsibility to protect the environment by maintaining their septic systems are misdirected.

The receiving sinks are OARs, but they are not amenable to privatization. The sinks that receive pollution from septic systems are OARs because it is not technologically practical to prevent septic system effluent from getting to the sinks. However, the receiving sinks cannot be divided into small portions and transferred to private ownership, which is the classic solution to managing OARs. In sum, classical solutions cannot be utilized to address the problem.

4.2 Features of sinks and households that lead to defection from maintenance and result in a divergence between private and public costs

In the absence of classical solutions, regulations remain the only viable option for controlling pollution from septic systems. To understand the nature of these regulations, however, requires a detailed 
understanding of the circumstances that lead households not to maintain their systems and the resulting divergence between private and public costs.

Initially, pollution from septic systems is dispersed and the consequences may go unnoticed. At the initial stages of pollution, the consequences are relatively minor and may be undetected. Indeed, the dispersed nature of the pollution explains why the problem stays under the "radar" for a long time, as observed by Orfield ([9], p. 169), and why, as noted by the USEPA [8], households do not observe failure until there is septage pooling on lawns or backups in basements, by which time serious damage may have already been done to water resources.

The characteristics of septic systems mean that it is difficult to trace pollution back to individual households. Although effluent is point source pollution at the moment it leaves a system, by the time it percolates through the drainfield and leaves the property of households it is non-point source pollution. In addition, the pollution is non-unique in that effluent from one household is not identifiably different than effluent from another. Thus, pollution cannot be traced to households unless targeted inspections are implemented. This could, for example, involve tracking different dyes placed in different systems, but this is a cumbersome and expensive exercise to perform on thousands of tanks and it therefore not likely to happen.

Circumstances mimic the prisoner's dilemma game. If Household A believes that neighboring households are not maintaining their systems, the public good would be polluted no matter what A does. Thus, unless A has an extremely strong civic ethic, like most people who use public goods when they observe others using them (e.g., non-toll roads), A is likely to defect from maintenance. On the other hand, if A believes that neighboring households are maintaining their systems, A has an incentive to free ride on their efforts because A knows that its lack of maintenance will hardly be noticed by anyone. As in the prisoner's dilemma game, regardless of what others do, Household A's best strategy is to defect from maintenance. Since all households face the same situation, the best strategy for all is to defect from maintenance. Indeed, given the likelihood of simultaneous defection among households, it is likely that septic systems in a subdivision will fail at the same time.

Private monitoring technology does not provide additional incentives for maintenance. While technological advances can warn households about impending failure [8], this does not fundamentally change the choices facing them. Household A, warned of a failure, will have little incentive to invest in maintenance if it believes that neighbors will ignore their own warnings. And as before, even if neighbors do respond to their warnings, it is still in Household A's self-interest to free ride on their efforts. Like before, all households will likely defect from maintenance.

Other public subsidies encourage defection from maintenance. There are numerous financial aid packages available to households to help them offset the private costs they can incur from failing systems, in particular for repairing systems or to assist in retrofitting subdivisions with public sewers [9]. The pressure for financial assistance arises precisely because, as noted earlier, systems in a subdivision will tend to fail together; thus there is likely to be a critical mass of households and a potentially widespread public health problem that demand attention.

Massachusetts appears to be a typical example of aid available to households. According to the Attorney General's Office in Massachusetts [60], assistance for repairing failing systems includes: (1) betterment funds so towns can make low-interest loans to qualified households; (2) subsidized home improvement loans; (3) FHA Title 1 loans; (4) a tax credit of \$1,500 per year to cover costs related to repairing or replacing systems; and (5) other low-interest loans.

According to Simonson [61], the largest source of funds to repair failing systems or retrofit areas with public sewers in North Carolina comes from Community Development Block Grants. Other federal sources include Clean Water Section 319(h) grants. At the state level, grants are available through the Clean Water Management Trust Fund. Regionally, the Southeast Rural Community 
Assistance Program provides low-interest loans to qualified households for system repair and replacement [61]. Simonson [61] also notes that 13 states have used State Revolving Funds to repair and replace failing systems. With these sources of subsidized funding available, there is less incentive for households to maintain their septic systems.

In summary, circumstances lead to the non-maintenance of septic systems by households and result in a divergence between private and public costs, where the public subsidizes the use of septic systems by households. There are four main factors:

1. the consequences of pollution are shared with the wider public;

2. it is difficult to identify polluters;

3. within each subdivision, the best strategy is for all households to defect from maintenance; and

4. the costs of remedial action are frequently subsidized by public dollars.

Education does not address these issues and making households aware of their systems and of the need to maintain them is an insufficient response to the problem. The divergence between private and public costs points to policies in which households should be required to internalize the externalities of utilizing septic systems.

\section{BEYOND THE HOUSEHOLD:}

SELF-INTEREST AT THE LOCAL GOVERNMENT LEVEL

An analysis shows that households' arguments for defecting from maintenance also apply to local governments. In particular:

1. The consequences of pollution may be shared with other jurisdictions outside the boundaries of the jurisdiction from which the pollution emanated.

2. It could be difficult to identify which jurisdiction is responsible for the pollution.

3. Within a collection of local governments likely to be affected by the problem, the best strategy is to defect from maintenance for the same reasons that defection is the best strategy for households. If Jurisdiction A believes that neighboring jurisdictions are not taking steps to ensure maintenance of their septic systems, then the public good would be polluted no matter what Jurisdiction A does. Likewise, if neighboring jurisdictions are taking steps to ensure maintenance, Jurisdiction A can free ride on their efforts.

4. The costs of remedial action are subsidized by the state and federal government.

In summary, like households, local governments face a divergence between their local costs and wider public costs when septic systems are employed, and it is therefore not in their rational selfinterest to establish effective regulations. This suggests that polices that force households to internalize the externalities of utilizing septic systems should be established at a higher level of government and be accompanied with incentives and sanctions to ensure implementation by local governments.

\section{ADDITIONAL CAVEATS}

Four additional caveats are in order. First, points 1, 2, and 3 of Section 5 assume that the jurisdictions are about the same size. The presence of a large jurisdiction relative to the size of the others could change the circumstances discussed above. For example, the large jurisdiction may bear the brunt of the negative effects of pollution, forcing it into unilateral action to address the problem or it may be 
easy to surmise that most of the pollution comes from the large jurisdiction. However, suburban and exurban areas in the United States are fragmented. While there may be a dominant central city, metropolitan areas usually comprise numerous smaller jurisdictions $[9,62]$ in which a single jurisdiction is not necessarily prominent.

Second, isolated rural areas may utilize septic systems for a long time without consequences or meaningful regulations because the low density of development in these areas means that the problem is unlikely to become a public issue. While it may become a private issue for a rural landowner, this will take a longer time to happen because - as a result of their size - rural parcels will likely have larger drainfields. It is also likely that there will be sufficient land on a rural parcel for a landowner to move the system to another site in the event of failure. However, this is not the case in suburbanized and exurbanized areas where densities are not as low and rapid development utilizing septic systems is not unusual.

Third, public goods theory predicts another interesting possibility with regard to rural areas. Rural areas may approach the "communal" standard of CPRs that can lead to proper management. In particular, households with septic systems may be the only ones affected by pollution of the sink; pollution of the sink may lead to the loss of the only source of drinking water; and the population may be sufficiently small to encourage cooperation and trust [55, 56, 63]. In sum, members of rural communities can have a strong interest to protect sinks from septic system pollution. However, I am not aware of such areas in the United States though I do not discount the possibility that they exist.

Fourth, I do not discount that households face private costs when septic systems fail, for example, from damaged lawns. However, these private consequences do not affect the preceding analyses for two reasons: First, private consequences are usually observed only after substantial damages to public goods have occurred and, second, as noted earlier, septic systems in an area will likely fail at the same time. Together, these two reasons ensure that the consequences of failure are widespread, which, in turn, compels public action in which the public subsidizes the costs faced by households, thus providing less incentives for the latter to maintain their systems.

\section{CONCLUSIONS AND POSSIBLE POLICY RESPONSES}

This article uses public goods theory to show that households do not maintain their septic systems because it is not in their rational self-interest to do so. Under these circumstances, educating households about their systems and of the need to maintain them will be an insufficient response. Similarly, it is not in the rational self-interest of local governments to establish effective regulations. State-established regulations, combined with incentives and sanctions to ensure implementation by local governments, appear to be a better solution.

To be sure, education is sometimes accompanied by regulations. For example, Massachusetts requires that systems be inspected at the time a house is sold to inform the buyer of their condition [64]. Minnesota, New Mexico, Wisconsin, Cayuga County in New York, and Washtenaw County in Michigan are representative of places with regulations. Additionally, Wisconsin requires a management plan for each system, mandates inspections, and allows counties to charge households for these. However, the vast majority of states and local governments do not have comparable regulations. Most states rely on basic regulations that govern issues such as the size of tanks, permitted lot sizes, distances to wells, etc., and these do not address issues related to maintenance.

In addition, regulations initiated at the local level appear to be weak and existing state-level regulations lack the necessary incentives and sanctions for effective implementation. For example, while Cayuga County has an inspection program, it is not clear what measures are taken against offending households and the inspection program is funded by public dollars, rather than charges to households with septic systems, thus providing a subsidy to these households. In counties on the Virginia 
side of Chesapeake Bay, households are only required to produce a receipt showing that they pumped their system once every 5 years, but there appears to be no sanctions against offenders.

With regard to the state level, in Massachusetts, for example, there is little effort to enforce maintenance during the intervening years when a house is not sold. Further, an inspection at the time of sale can be misleading because a house that is vacant for a few weeks can result in low levels of waste in the tank and deceptively dry soil around it (damp soil is the most common indicator of failure). Unless an inspector performs a detailed analysis, problems will go undetected. In Wisconsin, households' resistance to additional fees have resulted in local governments being unwilling to carry out inspections [65]; in the absence of state sanctions against local governments for non-compliance, local governments have few incentives to implement the regulations.

It is worth noting that areas with more attempts at regulation appear to be locations where the problems of pollution have become evident. This is consistent with public goods theory in that effective solutions are usually proposed only after the effects of the pollution become evident and are unacceptable [59]. In addition to those discussed above, other representative locations where regulations were intensified only after the emergence of problems include Los Osos and Stinson, California.

Potential policy solutions that minimize defection from maintenance and oblige households to internalize the externalities of utilizing septic systems include:

- Mandated periodic inspections of septic tanks performed by private licensed inspectors who are required to file the results at local government offices. Households without evidence of maintenance can be fined.

- Alternatively, inspections of septic systems could be performed by local government officials and households be billed by the local government.

- Mandated repairs when inspections uncover failure. Households would be required to present evidence of repairs and non-compliance would be a misdemeanor.

- A disclosure statement at the point of selling a house about past maintenance that is based on records on file at local government offices. This approach would discourage households from performing maintenance only at the point of selling the house.

- The continuous recording of information on the status and performance of septic systems. While such a policy may be controversial because of privacy concerns, it could be considered no different than the collection of information on water usage. Indeed, water usage information is now frequently collected by mobile electronic devices, and the same technology could be employed to retrieve information collected by devices installed on septic systems. Again, the costs for such operations should be borne by households.

- A clear statement in the title for new properties with septic systems that makes clear that no government subsidies will be available if officials determine that retrofitting with public sewers is needed. (It is tempting to suggest a policy where developers, as part of the approvals process, are required to deposit money into a fund that is sufficient to retrofit a subdivision with public sewers if and when required. However, the existence of such a fund would be another incentive not to maintain septic systems.)

While this article is not intended to take sides in the debate on the advantages or disadvantages of septic systems versus public sewers, the policy solutions that emerge from the analysis should help to inform those discussions. In particular, locations - in the United States or elsewhere - that allow the use of septic systems must be realistic about whether they possess the institutional and technological capacity to implement the necessary policies. Because this article was written with a focus 
on the United States, the recommendations outlined above reflect technology available in the United States.

One approach to implementing these policies at a higher level of government is to utilize regional governments. However, since effective regional governments exist in only a few areas in the United States, state-level implementation appears to be the best available option. Such an approach would be consistent with states' mandates for maintaining public health. Through state legislation, local governments could be mandated to implement the potential policies outlined above, accompanied with incentives and sanctions to ensure implementation.

It is useful to note that planners and policy makers are familiar with many other contexts in which self-interested behavior by individuals and local governments leads to a divergence between private and public costs. For example, self-interested behavior by individuals can lead to the overuse of parks ([52], p. 107), roads ([66], pp. 17-31; [67]), and water resources ([68], p. vii). Scholars have also used self-interested behavior to explain how fragmented local governments in the United States promote sprawl $[69,70]$, the debilitating effects of competition among local governments for economic development ([71], p. 99), and why local governments defect from attempts at regional governance [62].

In sum, regulations that require households to internalize the costs of utilizing septic systems and the need to implement these policies at the state level are consistent with well-established arguments in planning and policy making in the United States and are necessary to ensure that the use of septic systems is environmentally and fiscally sustainable. Education is not the primary solution to the problem of non-maintenance of septic systems by households.

\section{APPENDIX A: A REVIEW OF THE PRISONER'S DILEMMA GAME}

In the prisoner's dilemma game, two persons accused of committing a crime together have been captured by the police. They are put into separate cells and interrogated. Each knows the consequences - depending on what the other prisoner does - of either confessing to the crime or not. Figure A.1 displays the possible outcomes.

The first and second numbers represent years in jail for Prisoners 1 and 2, respectively. If Prisoner 1 believes that Prisoner 2 will confess, it is Prisoner 1's best strategy to also confess: Each will get a 5-year sentence (Box 1). If Prisoner 1 believes that Prisoner 2 will not confess, again Prisoner 1's best strategy is to confess: Prisoner 1 will get off with 0 years in jail by presenting evidence against Prisoner 2 who now receives the maximum sentence of 10 years (Box 2). Thus, no matter what Prisoner 2 does, Prisoner 1's best strategy is to confess.

\begin{tabular}{|c|c|c|}
\hline & \multicolumn{2}{|c|}{ Prisoner 2} \\
\hline & Confess & Does Not Confess \\
\hline Confess & $\begin{array}{c}5,5 \\
(\text { Box 1) }\end{array}$ & $\begin{array}{c}0,10 \\
(\text { Box 2) }\end{array}$ \\
\hline Does Not Confess & $\begin{array}{c}10,0 \\
(\text { Box 3) }\end{array}$ & $\begin{array}{c}1,1 \\
(\text { Box 4) }\end{array}$ \\
\hline
\end{tabular}

Figure A.1: Years in jail in the prisoner's dilemma game. 
Prisoner 2 faces the same choices. If Prisoner 2 believes that Prisoner 1 will not confess, Prisoner 2's best strategy is to confess (Box 3). Likewise, if Prisoner 2 believes that Prisoner 1 will confess, Prisoner 2's best strategy is still to confess (Box 1). Thus, the best strategy for both players, acting in their own rational self-interest, is to confess to the crime (also called a dominant strategy).

On the other hand, if both prisoners cooperate with each other, neither would confess to the crime, and both would end up in Box 4, each with only a 1-year prison term. However, once in Box 4, it is always in Prisoner 1's interest to defect from cooperation (i.e., to confess) in an attempt to move to Box 2. Likewise, it is always in Prisoner 2's interest to defect from cooperation in an attempt to move to Box 3. Because they both defect, they both end up in Box 1, which is a worse position than if they had cooperated and remained in Box 4.

\section{REFERENCES}

[1] U.S. Census Bureau, American Housing Survey for the United States: 2005, U.S. Census Bureau: Washington DC, 2006.

[2] NESC, Septic systems: a practical alternative for small communities. Pipeline, National Environmental Services Center, 15(3), pp. 1-7, 2004.

[3] Halvorsen, K.E. \& Gorman, H., Onsite sewage system regulation along the great lakes and the USEPA 'homeowner awareness' model. Environmental Management, 37(3), pp. 395-409, 2006.

[4] USEPA, Voluntary National Guidelines for Management of Onsite and Clustered (Decentralized) Wastewater Treatment Systems, USEPA: Washington, DC, 2003.

[5] Thompson, C.W., Nominees for board of directors. Onsite Journal: National Onsite Wastewater Recycling Association, 12(5), pp. 8-11, 2003.

[6] Chaffee, K.R., A cost-effective modular recirculating filter for on-site wastewater systems. Journal of Environmental Health, 63(4), p. 24, 2000.

[7] Rome, A.W., Building on the land: toward an environmental history of residential development in American cities and suburbs, 1870-1990. Journal of Urban History, 20(3), pp. 407-434, 1994.

[8] USEPA, Onsite wastewater treatment systems manual, USEPA: Washington, DC, 2002.

[9] Orfield, M., American metropolitics: The new suburban reality, Brookings Institution Press: Washington, D.C., 2002.

[10] Daniels, T.L., When city and country collide: Managing growth in the metropolitan fringe, Island Press: Washington, D.C., 1999.

[11] Harville, B., New tech, new trouble? Stepping up to the challenges of wastewater technology. Planning, 71(7), pp. 36, 2005.

[12] Schueler, T.R., Understanding watershed behavior. The Practice of Watershed Protection, eds T.R. Schueler \& H.K. Holland, Center for Watershed Protection: Ellicott City, MD, 2000.

[13] NOAA, Wastewater: the hidden threat of our nation's changing shoreline. Coastal Services, 7(3), pp. 5, 9, 2004.

[14] McKenzie, C.M., Onsite septic systems: educating the homeowner. Small Flows Quarterly, 3(1), pp. 14-17, 2002.

[15] Tonning, B., The beast in the backyard. State Government News, 44(2), pp. 22-24, 2001.

[16] Nelson, V.I., Dix, S.P. \& Shepard, F., Advanced On-site Wastewater Treatment and Management Scoping Study: Assessment of Short-Term Opportunities and Long-Run Potential, Electric Power Research Institute, the National Rural Electric Cooperative Association, and the Water Environment Research Federation, 1999.

[17] Nelson, A.C., Characterizing exurbia. Journal of Planning Literature, 6(4), pp. 350-368, 1992. 
[18] Hanson, M.E. \& Jacobs, H.M., Private sewage system impacts in Wisconsin: implications for planning and policy. Journal of the American Planning Association, 55(2), pp. 169-180, 1989.

[19] Lazarean, A., Septic system use in the U.S., unpublished paper, Department of Geography and Urban Planning, Wayne State University, Detroit, MI, 2006.

[20] Henderson, V., Urbanization in developing countries. World Bank Research Observer, 17(1), pp. 89-112, 2002.

[21] Nelson, A.C. \& Sanchez, T.W., Debunking the exurban myth: a comparison of suburban households. Housing Policy Debate, 10(3), pp. 689-709, 1999.

[22] Nelson, A.C. \& Dueker, K.J., Exurban living using improved water and waste-water technology. Journal of Urban Planning And Development-ASCE, 115(3), pp. 101-113, 1989.

[23] George, R.V., Formulating the right planning problem. Journal of Planning Literature, 8(3), pp. 240-259, 1994.

[24] NESC, Septic systems: a practical alternative for small communities. Pipeline, National Environmental Services Center, 6(3), pp. 1-2, 1995.

[25] Dowall, D.E., The Suburban Squeeze: Land Conversion and Regulation in the San Francisco Bay Area, University of California Press: Berkeley, 1984.

[26] Knaap, G., The price effects of urban-growth boundaries in Metropolitan Portland, Oregon. Land Economics, 61(1), pp. 26-35, 1985.

[27] Solomon, D. \& Dersch, E., What to do if your septic system fails, Michigan State University Extension, East Lansing, 1993.

[28] Swann, C., The influence of septic systems at the watershed level. Urban Lake Management, 3(4), pp. 821-834, 2001.

[29] USEPA, Response to Congress on use of decentralized wastewater treatment systems, USEPA, Washington, DC, 1997.

[30] McQuillan, D. Groundwater quality impacts from one-site septic systems. 13th Annual Conference of the National Onsite Wastewater Recycling Association, Albuquerque NM, 2004.

[31] Pinnette, S.R., Noble, W.T. \& Locke, D.B., Residential Septic System Impacts on Groundwater Quality in Maine: Characterization of Nitrate Concentrations in Domestic Wells at 18 Subdivisions, Maine Department of Environmental Protection: Augusta, ME, 1999.

[32] Evans, S., Hunt, S., Minahan, K. \& Zuckerman, M., Recommendations for Effective Septic System Management in the Upper Etowah Watershed, University of Georgia Institute of Ecology: Athens, GA, 1999.

[33] Cramlet, R. \& Turyk, N., An Evaluation of Past and Present Water Quality Conditions in Bear Lake, Waupaca County, Wisconsin, University of Wisconsin: Stevens Point WI, 2002.

[34] Washington Sea Grant, Health Hazards Associated with Sewage System Failure, University of Washington: Seattle, WA, 2006.

[35] Harris, P.J., Water quality impacts from on-site waste disposal systems to coastal areas through groundwater discharge. Environmental Geology, 26(4), pp. 262-268, 1995.

[36] Matuszeski, W., Notes from Bayside: even at their best, septic systems are bad for the Bay. Bay Journal, 7(1), pp. 28-31, 1997.

[37] Horsley Witten Group, Coastal Protection Program Workshops in Innovative Management Techniques for Estuaries, Wetlands, and Near COastal Waters, Prepared for USEPA, Office of Wetlands, Oceans, and Watersheds: Sandwich, MA, 1994.

[38] Fagergren, D., Tools for turning the tide of deteriorating water quality in shellfish growing areas: a decade of experience in Puget Sound, Washington State, USA. Journal of Shellfish Research, 18(2), pp. 715, 1999. 
[39] Taylor, C., Yahner, J. \& Jones, D., An Evaluation of On-site Technology in Indiana, Purdue University: West Lafayette, IN, 1997.

[40] Burgan, M.A. \& Sievers, D.M. On-Site Treatment of Household Sewage Via Septic Tank and Two Stage Submerged Bed Wetland, ASAE: Michigan, 1994

[41] Sierra Club Legal Defense Fund, The Poisoned Well: New Strategies for Groundwater Protection, Sierra Club: Washington, DC, 1989.

[42] Costanza, R., An Introduction to Ecological Economics, St. Lucie Press; International Society for Ecological Economics: Boca Raton, FL, 1997.

[43] NSFC, So ... Now you Own a Septic System, National Small Flows Clearinghouse, West Virginia University: Morgantown, WV, 1995.

[44] Volusia County, Everything You Always Wanted to Know about Septic Systems ... But Didn't Know Who to Ask! Volusia County, FL, 2003.

[45] NESC, What Do You Mean My House Has a Septic Tank? National Environmental Services Center: Morgantown, WV, 2003.

[46] University of Arizona Coop Extension, Inspecting Your Household Septic System, College of Agriculture and Life Sciences, The University of Arizona: Tucson, AZ, 2000.

[47] Silverman, G.S., The effectiveness of education as a tool to manage onsite septic systems. Journal of Environmental Health, 68(1), pp. 17-22, 2005.

[48] Gomez, A., Taylor, M. \& Nicola, R.M., Development of effective on-site sewage disposal surveys in King County, Washington. Journal of Environmental Health, 54(5), p. 20, 1992.

[49] Swann, C., A survey of residential nutrient behavior in the Chesapeake Bay, Center for Watershed Protection: Ellicott City, MD, 1999.

[50] Laffont, J.J., Fundamentals of Public Economics, MIT Press: Cambridge, MA, 1988.

[51] Cornes, R. \& Sandler, T., The Theory of Externalities, Public Goods, and Club Goods, 2nd edn, Cambridge University Press: Cambridge, 1996.

[52] Heikkila, E.J., The Economics of Planning, Center for Urban Policy Research: New Brunswick, NJ, 2000.

[53] Hopkins, L.D., Urban Development: The Logic of Making Plans, Island Press: Washington, DC, 2001.

[54] Turvey, R., On Divergences between Social Cost and Private Cost, in Economics of the Environment: Selected Readings, eds R. Dorfman \& N. Dorfman, W. W. Norton: New York, 1993.

[55] Ostrom, E., Governing the Commons: The Evolution of Institutions for Collective Action, Cambridge University Press: Cambridge, 1990.

[56] Ostrom, E., Reformulating the commons. Swiss Political Science Review, 6(1), pp. 29-52, 2000.

[57] Hardin, G., The tragedy of the commons. Science, 162(3859), pp. 1243-1248, 1968.

[58] Dorfman, R. \& Dorfman, N. (eds), Economics of the Environment: Selected Readings. W. W. Norton: New York, 1993.

[59] Davenport, D., Global Environmental Negotiations and US Interests, Palgrave Macmillan: New York, 2006.

[60] Massachusetts Attorney General \& Massachusetts Association of Realtors, Title 5 Facts for Consumers: Important Information REgarding Changes in SEptic SYstem Regulations, Boston, MA, n.d.

[61] Simonson, A., A Snapshot of Septic System REpair Funding in North Carolina: A Comprehensive Catalogue of Policy Options and Funding Resources, unpublished thesis, School of Government, University of North Carolina, Chapel Hill, NC, 2004.

[62] Basolo, V., US regionalism and rationality. Urban Studies, 40(3), pp. 447-462, 2003. 
[63] Olson, M., The Logic of Collective Action: Public Goods and the Theory of Groups, Harvard University Press: Cambridge, MA, 1965.

[64] Massachusetts State Environmental Code Title 5, Standard requirements for the siting, construction, inspection, upgrade and expansion of on-site sewage treatment and disposal systems and for the transport and disposal of septage. 310 CMR 15.000, 1995.

[65] Corry, M., A case study illustrating the need for a model performance code. Onsite Journal: National Onsite Wastewater Recycling Association 12(5), p. 6, 2003.

[66] Boarnet, M.G. \& Crane, R., Travel by Design: The Influence of Urban Form on Travel, Oxford University Press: Oxford, 2001.

[67] Heikkila, E.J., Microeconomics and planning: using simple diagrams to illustrate the economics of traffic congestion. Journal of Planning Education and Research, 14(1), pp. 29-41, 1994.

[68] Scholz, J.T. \& Stiftel, B., eds, Adaptive Governance and Water Conflict: New Institutions for Collaborative Planning, Resources for the Future: Washington, DC, 2005.

[69] Brueckner, J.K., Testing for strategic interaction among local governments: the case of growth controls. Journal of Urban Economics, 44(3), pp. 438-467, 1998.

[70] Nelson, A.C. \& Dawkins, C.J., Urban Containment in the United States: History, Models and Techniques for Regional and Metropolitan Growth Management, American Planning Association: Chicago, IL, 2004.

[71] Dreier, P., Mollenkopf, J.H. \& Swanstrom, T., Place Matters: Metropolitics for the TwentyFirst Century, 2nd edn, University Press of Kansas: Lawrence, KS, 2004. 